\title{
PENETAPAN KADAR FENOLIK TOTAL EKSTRAK ETANOL DAUN SERUNAI (Chromolaena odorata L.) DENGAN METODE SPEKTROFOTOMETRI UV-Vis
}

\author{
Risa Supriningrum ${ }^{1)}$, Henny Nurhasnawati ${ }^{1)}$, dan Siti Faisah ${ }^{1)}$ \\ ${ }^{1}$ Sekolah Tinggi Ilmu Kesehatan Samarinda \\ Email: risa.stikesam@gmail.com; henny_akfar@yahoo.ac.id; sitifaisah0110@gmail.com
}

\begin{abstract}
Serunai (Chromolaena odorata L.) is a medicinal plant, including the Asteraceae family. Serunai is used to treat wounds, mouthwash to treat sore throats, coughs, malaria drugs, headache medications, antidiarrheals, antimicrobials, antispasmodics, antihypertensive, anti-inflammatory and diuretic agents. Serunai plants contain chemical compounds tannins, phenols, flavonoids, saponins and steroids. The purpose of this study was to determine the total phenolic content of the leaves of serunai using the UV-Vis spectrophotometric method. The stages of the research include plant determination, sampling, making of simplicia leaf of serunai, making extract by maceration method, phenolic compound test, determination of total phenolic levels by UV-Vis spectrophotometry with Folin-Ciocalteu reagent, comparing gallic acid. The results obtained by an average of total phenolic levels of ethanol extract of serunai is $171.30368 \pm 1.9694 \mathrm{mg} \mathrm{GAE} /$ $\mathrm{g}$ means that in every gram of ethanol extract of flattened leaves is equivalent to $171,30368 \mathrm{mg}$ gallic acid.
\end{abstract}

Key words : Chromolaena odorata L, total phenolic, UV-Vis spectrophotometry, gallic acid, Folin-Ciocalteu

\section{PENDAHULUAN}

Serunai (Chromolaena odorata L.) adalah tumbuhan berkhasiat obat termasuk famili Asteraceae. Serunai digunakan untuk mengobati luka, obat batuk, obat malaria, obat sakit kepala, antidiare, antimikroba, diuretik, antispasmodik, antihipertensi, anti inflamasi. Tumbuhan serunai mengandung senyawa kimia tanin, fenol, flavonoid, saponin dan steroid (Vital dan Rivera, 2009). Berdasarkan hasil skrining fitokimia daun serunai mengandung senyawa alkaloid, flavonoid, saponin dan terpenoid (Zakaria , 2018)

Senyawa fenolik tersebar luas di alam dan memiliki variasi struktur yang luas, mudah ditemukan di semua tanaman, daun, bunga dan buah. Senyawa fenolik di alam yang telah diketahui strukturnya antaranya flavonoid, fenol monosiklik sederhana, fenil propanoid, polifenol (lignin, melanin, tanin), dan kuinon fenolik. (Muhlisah, 2008).

Senyawa fenolik merupakan senyawa yang memiliki cincin aromatik yang mengandung satu atau dua gugus hidroksil. Flavonoid merupakan golongan terbesar, tetapi fenol monosiklik sederhana, fenilpropanoid dan kuinon fenolik juga terdapat dalam jumlah besar. Beberapa golongan bahan polimer penting dalam tumbuhan seperti lignin, melanin dan tanin adalah senyawa polifenol dan kadang-kadang satuan fenolik dijumpai pada protein, alkaloid dan terpenoid (Harbone, 1987). Kemampuan senyawa fenolik sebagai senyawa biologik aktif memberikan peran besar terhadap kepentingan manusia. Salah satunya sebagai antioksidan untuk pencegahan atau pengobatan penyakit degeneratif seperti kanker, penuaan dini dan gangguan sistem imun tubuh (Apsari dan Susanti, 2011).

Penetapan kadar fenolik dapat dilakukan dengan metode Spektrofotometri UV-Vis karena gugus hidroksil pada komponen fenolik dengan reagen Folin Ciocalteu menghasilkan warna biru yang dapat dideteksi dengan spektrofotometri UVVis (Alfian dan Susanti, 2012).

Mengingat pentingnya senyawa fenolik bagi kesehatan manusia. Maka untuk memaksimalkan pemanfaatan daun serunai perlu dilakukan penelitian tentang penetapan kadar fenolik total tumbuhan serunai menggunakan metode Spektrofotometri UVVis dengan reagen Folin-Ciocalteu, dan sebagai pembanding digunakan asam galat. 


\section{METODE PENELITIAN}

\section{Alat dan Bahan}

Alat yang digunakan pada penelitian adalah alat-alat gelas (Pyrex), maserator, mikropipet skala 100-1000 $\mu \mathrm{L}$ (Viltab), neraca analitik (Ohaus), Spektrofotometer UV-Vis (Shimadzu).

Bahan yang digunakan adalah aquades, asam galat, daun serunai, etanol 70\%, Folin Ciocalteau, natrium karbonat dan pereaksi besi (III) klorida $1 \%$.

\section{Prosedur Kerja}

\section{Pengambilan dan Pengolahan sampel :}

Sampel daun serunai diperoleh di sekitar kelurahan Air Hitam, Samarinda, pada bulan Desember 2018. Ciri daun serunai yang digunakan adalah bentuk daun bulat telur , tepi daun bergerigi, susunan tulang daun melengkung dan apabila daun diremas akan menimbulkan bau khas. Sampel daun yang telah dikumpulkan, disortasi basah, dicuci, dikeringkan dan dilakukan sortasi kering. Selanjutnya simplisia dihaluskan hingga diperoleh simplisia serbuk dengan derajat kehalusan tertentu.

\section{Ekstraksi daun serunai}

Sampel ditimbang sebanyak 100 gram , dimaserasi dengan etanol $70 \%$, selama 24 jam dan dilakukan pengadukan kontinyu pada 2 jam pertama. Selanjutnya disaring dan ampas dimaserasi kembali dengan jumlah dan jenis pelarut sama. Ekstrak cair yang diperoleh diuapkan hingga diperoleh ekstrak kental, dan dihitung rendemennya.

$$
\% \text { Rendemen }=\frac{\text { bobot ekstrak }(g)}{\text { Bobot simplisia yang diekstrak }(g)} \times 100 \%
$$

\section{Analisis kualitatif kandungan fenolik}

Identifikasi senyawa fenolik dilakukan dengan mengambil sejumlah sampel ditambahkan dengan pereaksi $\mathrm{FeCl}_{3} \quad 1 \%$ sebanyak 3 tetes. Terjadinya warna hijau biru menunjukkan adanya senyawa polifenol (Alfian dan Susanti, 2012).

\section{Analisis kuantitatif}

a. Penentuan panjang gelombang maksimal

Panjang gelombang maksimal asam galat dilakukan dengan mengukur larutan asam galat konsentrasi $30 \mathrm{ppm}$ pada range $600-850 \mathrm{~nm}$ dan ditentukan nilai panjang gelombang maksimum dengan nilai absorbansi tertinggi (Andriani dan Murtisiwi, 2018).

b. Pengukuran larutan seri standar asam galat
Dibuat larutan seri standar asam galat dengan konsentrasi 10, 20, 30, 40 dan 50 ppm yang diperoleh dengan cara mengencerkan larutan induk asam galat $1000 \mathrm{ppm}$. Kemudian ditambahkan 1,5 $\mathrm{ml}$ reagen Folin Ciocalteau, dikocok dan dibiarkan 3 menit. Ditambahkan 1,2 ml larutan $\mathrm{Na}_{2} \mathrm{CO}_{3} 7 \%$, dikocok hingga homogen. Didiamkan selama 60 menit pada suhu ruangan dan diiukur absorbansinya pada panjang gelombang maksimal . Dibuat kurva kalibrasi hubungan antara konsentrasi asam galat $(\mu \mathrm{g} / \mathrm{ml}$ ) dengan absorbansi (Ahmad dkk, 2015; Andriani dan Murtisiwi, 2018).

c. Penetapan Kadar Fenolik sampel

Sebanyak $10 \mathrm{mg}$ ekstrak etanol daun serunai dilarutkan dalam $10 \mathrm{ml}$ campuran etanol ; aquades (1:1). Larutan ekstrak yang diperoleh dipipet $0,3 \mathrm{ml}$ ditambah reagen Folin-Ciocalteau dikocok dan diamkan selama 3 menit, ditambahkan larutan $\mathrm{Na}_{2} \mathrm{CO}_{3} 7 \%$ sebanyak $1,2 \mathrm{ml}$, didiamkan selama 60 menit pada suhu kamar. Absorbansi larutan ekstrak diukur dengan Spektrofotometri UV-Vis pada panjang gelombang maksimumdan dilakukan pengulangan (Andriani dan Murtisiwi, 2018).

Kadar Fenolik dihitung dengan rumus:

$$
\text { TPC }\left(\text { Total Phenolic Content }=\frac{c x v}{g}\right.
$$

Keterangan: $\mathrm{c}=$ konsentrasi fenolik (nilai $\mathrm{x}$ )

$\mathrm{v}=$ volume ekstrak yang digunakan

$\mathrm{g}=$ berat sampel yang digunakan

\section{HASIL DAN PEMBAHASAN}

Skrining fitokimia senyawa fenolik terhadap ekstrak etanol daun serunai menggunakan pereaksi $\mathrm{FeCl}_{3} 1 \%$ memberikan hasil positif, yang ditandai dengan terbentuknya warna hijau . Hasil uji polifenol positif, bila terjadinya reaksi antara senyawa polifenol dan $\mathrm{FeCl}_{3}$ membentuk kompleks berwarna hijau, ungu, biru (Apsari dan Susanti, 2011).

Penetapan kadar fenolik total dilakukan dengan pereaksi Folin-Ciocalteau, karena senyawa fenolik dapat bereaksi dengan Folin-Ciocalteau membentuk larutan yang dapat diukur absorbansinya (Sari dan Ayuchecaria, 2017). Reagen FolinCiocalteau mengoksidasi gugus hidroksil dari senyawa golongan fenol membentuk kompleks berwarna biru. Reaksi ini berjalan lambat pada suasana asam sehingga pada pengujian ditambahkan 
natrium karbonat untuk membentuk suasana basa dan reaksi dapat berjalan lebih cepat (Lestari $\mathrm{dkk}, 2014)$

Larutan standar yang digunakan adalah asam galat yang merupakan salah satu fenolik alami dan stabil. Asam galat termasuk dalam senyawa fenolik turunan asam hidroksibenzoat yang tergolong asam fenolik sederhana. Asam galat direaksikan dengan reagen Folin-Ciocalteau menghasilkan warna kuning yang menandakan bahwa mengandung fenolik, kemudian ditambahkan dengan larutan natrium karbonat sebagai pemberi suasana basa. Selama reaksi berlangsung, gugus hidroksil pada senyawa fenolik bereaksi dengan reagen FolinCiocalteau membentuk kompleks molibdenumtungsten berwarna biru. Warna biru yang terbentuk akan semakin pekat, setara dengan konsentrasi ion fenolak yang terbentuk, artinya semakin besar konsentrasi senyawa fenolik maka semakin banyak ion fenolak yang akan mereduksi asam heteropoli (fosfomolibdat-fosfotungstat) menjadi kompleks molibdenum-tungsten sehingga warna yang dihasilkan semakin pekat (Sari dan Ayuchecaria, 2017).

Sebelum menentukan kadar fenolik total ekstrak etanol daun serunai, terlebih dahulu dilakukan penentuan panjang gelombang larutan standar asam galat dari range 600- $850 \mathrm{~nm}$ menggunakan spektrofotometri UV-Vis. Panjang gelombang maksimal yang diperoleh yaitu $748 \mathrm{~nm}$. Selanjutnya dilakukan pengukuran absorbansi larutan seri standar asam galat pada panjang gelombang maksimal tersebut. Penetapan panjang gelombang maksimum bertujuan untuk mengetahui besar panjang gelombang yang dibutuhkan larutan asam galat untuk mecapai serapan maksimum.

Hasil pengukuran absorbansi larutan standar asam galat dibuat kurva kalibrasi hubungan antara konsentrasi (C) dengan absorbansi (A) dan diperoleh persamaan garis linear (Gambar 1).

Hasil analisis diperoleh persamaan garis linear untuk absorbansi asam galat sebesar $\mathrm{y}=$ $0,010263 \mathrm{x}+0,00965$ dengan nilai koefisien korelasi (r) sebesar 0,99798 yang digunakan untuk menentukan kadar fenolik pada sampel. Kadar ratarata fenolik total ekstrak etanol daun serunai adalah $171,3037 \pm 1,9694 \mathrm{mg}$ GAE/ $\mathrm{g}$ yang berarti dalam setiap gram ekstrak etanol daun serunai setara dengan 171,3037 $\mathrm{mg}$ asam galat.

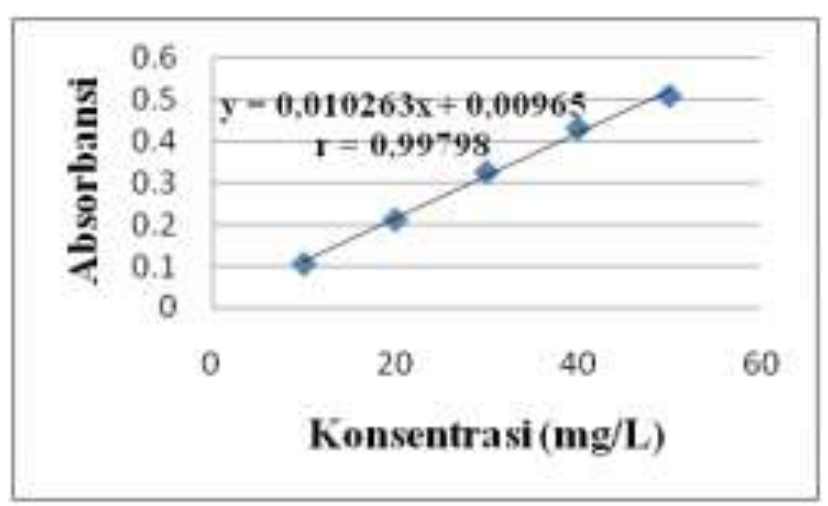

Gambar 1. Kurva kalibrasi asam galat

Tabel 1. Kadar fenolik total

\begin{tabular}{|c|c|c|}
\hline No & Kadar (mg GAE/g) & Rata-Rata Kadar \pm SD \\
\hline 1 & 168,2695 & \multicolumn{1}{|}{} \\
\hline 2 & 173,5701 & \multirow{2}{*}{$171,3037 \pm 1,9694$} \\
\hline 3 & 171,7967 & \\
\hline 4 & 170,7736 & \\
\hline 5 & 172,1085 & \\
\hline
\end{tabular}

Hasil ini mendekati kadar fenolik total pada daun beluntas yaitu 190,02 $\pm 11,4521 \mathrm{mg} \mathrm{GAE} / \mathrm{g}$. Tumbuhan serunai dengan tumbuhan beluntas memiliki famili yang sama yaitu Asteraceae. Senyawa fenolik mempunyai kemampuan sebagai antioksidan untuk pencegahan atau pengobatan penyakit degeneratif seperti kanker, penuaan dini dan gangguan sistem imun tubuh (Apsari dan Susanti, 2011).

\section{KESIMPULAN}

Rata-rata kadar fenolik total ekstrak etanol daun serunai (Chromolaena odorata L.) adalah $171,3037 \mathrm{mg} \pm 1,9694 \mathrm{mg} \mathrm{GAE} / \mathrm{g}$ artinya dalam setiap gram ekstrak etanol daun serunai setara dengan $171,3037 \mathrm{mg}$ asam galat.

\section{DAFTAR PUSTAKA}

Ahmad, A.R., Juwita., Ratulangi S.A., dan Malik, A, 2015. "Penetapan Kadar Fenolik dan Flavonoid Total Ekstrak Metanol Buah dan Dun Patikala (Etlingera elatior (Jack)R.M.SM)". Jurnal Pharmaceutical Sciences dan Research. Volume 2 (1). Hal : 34.

Alfian, R., dan Susanti, H. 2012, "Penetapan Kadar Fenolik Total Ekstrak Metanol Kelopak Bunga Rosella Merah (Hibiscus sabdariffa 
Linn) Dengan Variasi Tempat Tumbuh Secara Spektrofotometri”. Jurnal Ilmiah Kefarmasian. Yogyakarta: Universitas Ahmad Dahlan. Hal: 78.

Andriani, D. dan Murtisiwi, L. 2018, "Penetapan Kadar Fenolik Total Ekstrak Etanol Bunga Telang (Clitoria ternatea L.) Dengan Metode Spektrofotometri UV Vis". Cendekia Journal of Farmasi. Hal: 32-37.

Apsari, P.D., dan Susanti, H, 2011. "Perbandingan Kadar Fenolik Total Ekstrak Metanol Kelopak Merah dan Ungu Bunga Rosella (Hibiscus sabdariffa, Linn) Secara Spektrofotometri". Jurnal Fakultas Farmasi Universitas Ahmad Dahlan. Hal: 73-77.

Harbone, J.B. 1987, Metode Fitokimia. Bandung: ITB. Hal: 21, $23,47$.

Lestari, T., Rahmiyani, L., Munawaroh, S. 2014, "Pengaruh Metode Dan Variasi Pelarut Ekstraksi Terhadap Kadar Polifenolat Bunga Kecombrang". Jurnal Kesehatan Bakti Tunas Husada. 12(1): 92.

Muhlisah, F. 2008, Tanaman Obat Keluarga (TOGA). Penebar Swadaya. Jakarta.

Sari, A.K., dan Ayuchecaria, N, 2017, "Penetapan Kadar Fenolik Total Dan Flavonoid Total Ekstrak Beras Hitam (Oryza sativa L) Dari Kalimantan Selatan” Jurnal Ilmiah Ibnu Sina. Hal: 332.

Vital, P., \& Rivera, W, 2009, Antimicrobacterial activity and citoxicity of Chromolaena odorata L.f., King and Robinson and Uncaria perrottetii (A. rich) Merr. Extracts. Journal of Medical Plant Research, 3 (7), 511-518.

Wahyuni, S. 2018, "Penetapan Kadar Fenolik Total Ekstrak Etanol Daun Beluntas (Pluchea indica L.) Dengan Metode Ekstrasi dan Maserasi". Karya Tulis Ilmiah. Samarinda : Akademi Farmasi Samarinda. Hal: 31.

Zakaria, M.M., 2018, "Uji Toksisitas Akut Ekstrak Etanol Daun Serunai (Chromolaena odorata L.) Dengan Metode Brine Shrimp Lethality Test (BSLT)". Karya Tulis Ilmiah. Samarinda: Akademi Farmasi Samarinda. 